\title{
Defining and Quantifying the Pension Liabilities of Government Entities in the United States
}

\section{Authors: Nathan H. Jepsen, John A. Ruddy, and David F. Salerno}

This is the peer reviewed version of the following article: see citation below, which has been published in Journal of Corporate Accounting and Finance final form at https://dx.doi.org/10.1002/ jcaf.22320. This article may be used for non-commercial purposes in accordance with Wiley Terms and Conditions for Self-Archiving.

Jepsen, Nathan H. , John A. Ruddy, and David F. Salerno. "Defining and Quantifying the Pension Liabilities of Government Entities in the United States." Journal of Corporate Accounting and Finance 29, no. 1 (January 2018). DOI:10.1002/jcaf.22320. 


\title{
Defining and Quantifying the Pension Liabilities of Government Entities in the United States
}

\author{
Nathan H. Jeppson, John A. Ruddy, and David F. Salerno
}

\section{INTRODUCTION}

The Wall Street

Journal recently reported that the current low-interestrate environment has reduced asset values in the world's largest pension funds by $\$ 530$ billion. As central banks lowered interest rates during and after the financial crisis to help improve economic conditions, more than 100 million government workers' and retirees' pensions worldwide became seriously threatened (Martin, Kantchev, \& Narioka, 2016). In 2016, Moody's Investors Service (Moody's) estimated that U.S. federal, state, and local government employee pension plans were underfunded by about

In today's low interest rate environment, accounting standards and investment return assumptions are crucial when determining the amount of defined benefit pension plan obligations. Examining public pension plan data provided by the U.S. Census Bureau, we show a negative trend in pension plan liabilities of government entities in the U.S. Despite using aggressive return and discount rate assumptions, defined benefit pension plans of government entities in the U.S. currently have an estimated pension liability of over $\$ 1$ trillion. When more realistic investment assumptions are utilized, the estimated defined benefit pension liability increases to over $\$ 5$ trillion. Although over the past twenty years, while many for-profit companies have eliminated defined benefit pension plans years to avoid the risk of underfunding, a high percentage of federal, state and local governments continue to offer defined benefit pensions plans to new and current employees. This has led to growing pension liabilities for government entities in the U.S. resulting in problematic financial positions, difficult decisions, and grim future outlooks. O 2018 Wley Periodicals, Inc.

\$7 trillion, with \$3.5 trillion (equal to approximately $20 \%$ of the U.S. gross domestic product [GDP]) coming from the underfunded defined benefit (DB) obligations of federal government employees (Bryan, 2016). Furthermore, investment return assumptions made by government entities are likely too optimistic. For example, even if government pensions averaged a $7.6 \%$ return per year in perpetuity, the pension plans would still be underfunded by $\$ 1.2$ trillion (Matthews, 2016). This problem extends beyond U.S. borders as well. In 2016, Citibank reported that underfunded government pension liabilities for the 20 OECD (Organisation for Economic Cooperation and Development) nations were estimated to be $\$ 78$ trillion, which was $177 \%$ of 
the amount of all other government debt combined for the same countries. Although the urgency of the problem seems to demand immediate pension reform, the issue does not seem to alarm young workers, who are most vulnerable. Younger workers, understandably more concerned with student loans and housing costs, are generally unaware that $\mathrm{DB}$ pensions are underfunded and believe that there is plenty of time to make corrections if needed (Edwards, 2016).

The private sector, however, has made great strides to tackle the issue of underfunded DB pension plans. Fortune 500 companies have all but eliminated DB plans, and have migrated to defined contribution (DC) plans (McFarland, 2016). By 2015 only $20 \%$ of Fortune 500 firms still carried DB plans for new employees, down from 59\% in 1995 (McFarland, 2015). In contrast, according to the U.S. Bureau of Labor Statistics, $85 \%$ of all state and local government employees had access to a DB plan as of March 2016 (available at https://www.bls.gov/ ncs/ebs/benefits/2016/benefits_ retirement.htm).

\section{INFORMATIONBACKGROUND ONPENSIONS}

DB and DC plans are the two basic plans offered to workers. Traditionally in the United States, employers provided employees with DB plans. In such cases, the employer calculated and provided employees retirement income and benefits amount based on a formula computation. Employers considered factors such as length of employment service and salary history to calculate the amount of benefits provided during retirement. The employer bore responsibility for pension plan administration. It also bore the risks of the DB plan, which included investment risk, regulatory risk, and actuarial risk, among others. When the projected benefits due to employees were greater than the market value of financial assets in the DB plan, accounting rules mandated that employers recognize a liability in its financial statements. As a result of the aforementioned burdens and risks, many employers replaced DB plans with DC plans. Over the past several decades, employers have saved significant resources and monies by switching to DC plans, as the benefits offered are typically less generous than DB plans. In a DC plan, employers have an obligation to contribute an amount typically equal to a percentage of an employee's salary. In contrast to DB plans, in DC plans employers have no investment risk or liability recognition. Rather, the employee bears the investment risk associated with retirement plan assets. If the performance of the DC plan is less than expected, the employer does not recognize a liability. Moreover, the employer is not required to dedicate any resources to managing the DC plan.

\section{ISSUESWITHUNDERFUNDED PUBLICPENSIONS}

The obvious problem with underfunded DB pension plans is that of being unable to satisfy commitments to government pensioners. However, there is also a ripple effect that underfunded DB pensions have, which can be far more pervasive. Killian, Faulk, and Hicks (2016) indicate that there are hidden costs to the underfunded pension plans of government entities. Potentially negative consequences include the following:

\section{Reducedspendingonpublic} services. Generally, government entities in the United States are funded by taxpayer contributions and exist to provide public services. Heavily burdened with DB pension obligations, governmental entities often need to reduce spending on other services to compensate for the DB shortfall. Many of those cuts affect the quality of life in communities. This reality has hit both state and local systems. For example, Fletcher (2014) reported that San Jose, California, reduced spending on infrastructure and cut city services including library and recreation center hours, due in large part to their pension obligations. Katz (2017) reports that according to business leaders in the state of Michigan, retirement bene $₫ \mathrm{t}$ obligations "represent signi冈cant long-term risks to the $\bigotimes$ scal stability of schools, local governments and, indirectly, the state." Sigo (2016) indicates that transportation spending was cut in the state of Kentucky in 2016 after dumping billions of dollars into the state's underfunded pensions.

2. Increasedcontributionsand coststoemployees. T ypically, government employees fund a portion of their own retirement plans. Underfunded pension plans often require that public 
employees increase their contributions. Attmore and Ives (2015) report that New Jersey public workers have been made to increase their contributions and to eventually receive fewer bene冈ts in their retirement years. Making matters worse, of $\bigotimes$ cials sometimes $\unrhd$ nd creative ways to balance budgets and cut spending on current services by promising future bene囚ts. For example, Bagchi (2014) 冈nds that "some policymakers have been able to extract short-term wage concessions in exchange for pension expansions that are due long after they have left of $₫$ ce," thus delaying, but not solving pension problems.

3. Bondholderslosevalue. Investors in municipal bonds have increased risk of loss due to underfunded DB plans. Aneiro (2014) reported that although traditionally "bondholder claims on any defaulted municipal government's assets have had legal priority over public employee bene $\bigotimes$ ts and payments owed to pension funds," recent developments may signal a shift in that practice. Municipal bankruptcy court cases involving the cities of Stockton and Detroit have forced losses on bondholders in favor of pensioners. Moody's stated that "the disparate treatment of pension obligations and investor-owned obligations means that pensioners are likely to enjoy better treatment than general government debt in Michigan and California Chapter 9 cases, and potentially in bankruptcies $\bigotimes$ led in other states" (Farmer, 2014).
Five reasons have been offered to explain why debt repayment might be problematic when the entity carries underfunded pension obligations; $\bigotimes$ rst, as pension costs are not $\nabla x e d$, the assumptions used to calculate the debt must be continuously aligned with the actual obligations; second, pension debt is growing at an extraordinary rate; third, no regulatory restrictions exist on the amount of pension debt a local government may carry; fourth, pension liabilities change with stock market volatility; and $\nabla \mathrm{fth}$, pension obligations have started to take priority over municipal bondholders (Shane \& Woeppel, 2015, p. 21). Each of these factors increase the risk associated with investing in municipal bonds.

4. Of囚cials aremoti vatedto makeriskyinvestments. Attempting to shore up pension obligations, public of cials often chase highpotential returns and as a result make risky investments (Killian et al., 2016). As policymakers grapple with underfunded pension plans, they increasingly look for other investments that carry higher potential returns. Unfortunately, the higher potential returns are commensurate with higher risk. Thus, hidden costs stem from these subsequent investments made with pension fund assets with the intention of quickly $\triangle x i n g$ the problem. One signi冈cant example is the San Diego County Employees Retirement Association, which resorted to "complex derivatives to supercharge its bets as it looks to cover a funding shortfall and diversify its holdings" (Fitzpatrick \& Martin, 2014). As a result, the county taxpayers have taken signi冈cant risk as a result of the government's investment strategy.

5. Lowercreditr atingsand higherborrowingcosts. According to their research, Killian et al. (2016) \nd that the two most signi冈cant hidden costs of underfunded pensions are lower credit ratings and higher borrowing costs. They indicate that between "2010 and 2013, Moody's Investors Service downgraded the credit ratings of six states due largely to growing pension liabilities." There are numerous examples of such credit downgrades at state and local levels. Devitt and Shields (2014) report that the city of Chicago, the park district, the school system, the county forest preserve district, and the water reclamation district have all experienced credit rating downgrades largely due to their underfunded pension obligations. Other notable downgrades include the states of Illinois and New Jersey, as well as the cities of Houston, Texas, and Santa $\mathrm{Fe}$, New Mexico. Credit rating downgrades, underfunded pensions, and thus higher costs of borrowing all work together to further diminish the 冈nancial health of a community. Underfunded DB pensions can mask the true cost of public services and they can lead to overspending. Finally, as taxpayers are ultimately responsible for the obligations of the jurisdiction, underfunded DB pensions can also lead 
to a drop in local real estate values (Killian et al., 2016, p. A1).

\section{THEEFFECTOFPENSION DISCOUNTRATES}

Many factors and assumptions impact the size of DB pension liabilities. The factors include employee mortality rates, future inflation estimates, and employee turnover estimates. The discount rate used to calculate the present value of pension liabilities, however, might have a more dramatic effect on the value of the accrued pension liabilities than any other factor. The discount rate represents the reduction in the value of scheduled future pension payments due to the time value of money. The pension payments are made to retired employees as part of their deferred compensation package. The time value of money discount is based on the assumption that plan assets will earn a reasonable rate of return between the time that assets are contributed to the pension plan and the time that they are paid to employees as part of their retirement pension payments. Ceteris paribus, higher pension plan discount rates result in lower present values of pension obligations and lower pension plan discount rates result in higher present values of pension obligations.

An example of the relationship between the discount rate and DB pension plan liability is as follows: the state of California has a $\mathrm{DB}$ pension plan that currently has a $\$ 450$ billion liability, which represents the difference between the current market value of pension plan assets and the estimate of the present value of payments due to pension plan recipients in the future. While an estimated shortfall of that magnitude is enough to warrant significant concern, the deficit assumes a high discount rate of $7.5 \%$ to $8.0 \%$. In recent years, pension plans have struggled to attain these optimistic returns. If pension fund managers were forced to reduce the discount rate to more conservative rates similar to the rates that private corporate retirement plans use, California's deficit in pension plan assets compared to their discounted future liability could balloon to well over $\$ 1$ trillion (Walters, 2016). Changes in discount rates for other pension plans tell a similar story. The Retirement Board for the Fireman's Annuity and Benefit Fund of Chicago made a minor adjustment in their discount rate from $8.0 \%$ to $7.5 \%$. This slight adjustment, a change of only $0.5 \%$, resulted in an increase of $\$ 188.2$ million of the estimated unfunded liability for the fund (Civic Federation, 2016).

The reasoning behind the discount rate is relatively straightforward; it reflects the present value of the estimated future payments to retirees covered by a specific pension plan. However, the logic regarding what the discount rate reflects is the subject of debate. There are basically two approaches to arriving at an appropriate discount rate. One approach is that the discount rate should reflect a risk-free approach since public pension plans are guaranteed payments to plan recipients (Faulk, Hicks, \& Killian, 2016). The other approach is to estimate a discount rate based on a reasonable long-term rate of return on plan assets since those assets can be invested to generate a return between the time they are contributed and the time that payments are made to recipients (Elder \& Wagner, 2016).

For fiscal years beginning after June 15, 2014, the new Governmental Accounting Standards Board (GASB) Statement No. 68 (Accounting andFinancialReportingfor Pensions) provides guidance regarding what discount rate should be used. Specifically, GASB 68 requires projected future payments

tobediscountedtotheir
actuarialpresentvalue
usingthesingleratethat
reflects (1)along-term
expectedrateofreturn
onpensionplaninvest-
mentstotheextentthat
thepensionplan'sfidu-
ciarynetpositionispro-
jectedtobesufficientto
paybenefitsandpension
planassetsareexpected
tobeinvestedusinga
strategytoachievethat
returnand(2)atax-
exempt, high-quality
municipalbondrate
totheextentthatthe
conditionsforuseof the
long-termexpectedrate
ofreturnarenotmet.

(GASB,2012)

Implementation of the guidance of GASB 68 and its new directives regarding discount rates has already garnered significant attention from state and local governments, regulators, and other interested stakeholders (Folton, Flesher, Previts, \& Stone, 2017). However, research has shown that not all guidance from the GASB has been effectively 
implemented. For example, after reviewing the financial statements of over 30,000 state and local governments in 2008, the GASB found that roughly $30 \%$ do not follow GASB reporting standards (Mead, 2008). Still, some researchers have attempted to estimate changes in pension liabilities that would result by using the guidance provided by GASB 68. One study reviewed 48 large, state-administered pension plans and found that their average funded ratio decreased from $73.4 \%$ to $56.3 \%$ (Mortimer \& Henderson, 2014). This means that, on average, state-administered plans had $\$ 0.56$ in assets for each $\$ 1.00$ in present value of future obligations. Other studies regarding the implementation of GASB 68 report similar changes to pension funding ratios (Collins \& Rettenmaier, 2010; Farmer \& Maciag, 2015). While the discount rate selected by a pension plan is just one factor among many that determine the funding status of a pension system, it has clearly been shown to be a significant one. Administrators of DB plans should carefully select conservative discount rates to ensure that they can confidently meet future financial obligations without sacrificing the functionality of their current, essential services. Regardless of the discount rate that is selected, pension plan administrators and governmental decision makers should recognize the importance that pension plan obligations represent and the dangerous threats that could be faced if serious attention is not given to these obligations and the effects that they pose to the future successful operation of states and municipalities alike.

\section{PENSIONDATAANDANALYSIS}

The primary data for this research comes from the United States Census Bureau (USCB). Each year, the USCB conducts a survey of public pensions which includes defined benefit plans for local and state governments. The USCB provides pension data on each and local and state government for the previous year. For example, in May 2017 the USCB released data for the fiscal year 2016. The data can be accessed at https://www.census.gov/govs/ retire/. The USCB website provides data on each of the 50 states, including all of the local municipalities of each state, as well as the District of Columbia. It also provides the data for all states and the District of Columbia combined. The data includes information on each pension plan, which includes, among other data, the contributions made by plan participants and governments during the year, total payments made to plan beneficiaries during the year, types of financial assets and market value of financial assets, and the number of and details on the plan participants. Finally, the data includes a current estimate of each state's pension obligation (liability).

Overall, the 2015 USCB pension plan data indicates that the pension plans for the 50 states excluding plans involving local governments, held financial assets with approximately $\$ 3.1$ trillion in market value as of the end of the 2015 fiscal year. The present value of the pension obligations for the same pension plans was approximately $\$ 4.1$ trillion. Thus, public pension plans administered by the 50 U.S. states were approximately $\$ 1.0$ trillion dollars ( $\$ 4.1$ trillion $\$ 3.1$ trillion) underfunded as of the end of the 2015 fiscal year. It also means that the ratio of value of plan assets to pension obligation is approximately $76.1 \%$ (\$3.1/\$4.1 trillion).

The pension data indicate that the majority of states have pension plan obligations that exceed the market value of pension plan assets. In 2015, only 5 states (Georgia, Maine, South Dakota, Tennessee, and Wisconsin) had pension plan assets that exceeded the state's pension plan obligations. The remaining 45 states had pension plan obligations that were greater than the market value of the pension plan assets. For example, 8 states had a market value of pension plan assets that between $90 \%$ and $100 \%$ of plan obligations, and 8 states had a market value of pension plan assets that between $80 \%$ and $90 \%$ of plan obligations. Additional details concerning the market value of pension plan assets for each of the 50 state pension plans (excluding local governments) are shown in Exhibit 1.

As the bar graph in Exhibit区 indicates, 15 states had a market value of plan assets that was between $60 \%$ and $70 \%$ of the projected pension obligation.

Overall, the 2016 USCB pension plan data indicates that the pension plans for the 50 states excluding plans local governments, hold financial assets with approximately $\$ 3.1$ trillion in market value as of the end of the 2016 fiscal year, roughly the same as 2015 . However, the present value of the pension obligations for the same pension plans was approximately $\$ 4.2$ trillion, $\$ 100$ million higher than 2015. 


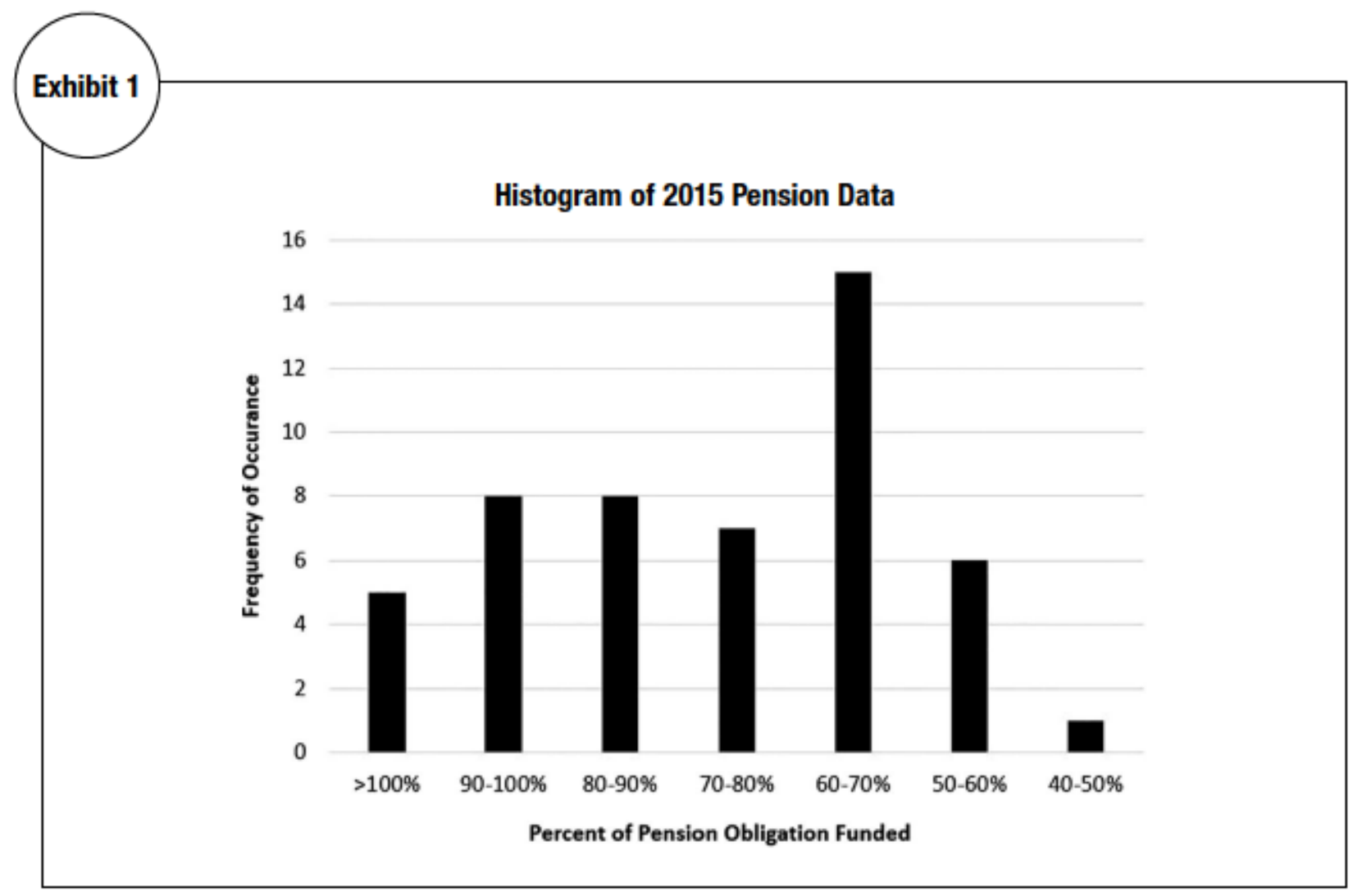

Thus, the net pension obligation of the public pension plans administered by the 50 U.S. states was underfunded by approximately $\$ 1.1$ trillion dollars as of the end of the 2016 fiscal year. It also means that the ratio of value of plan assets to pension obligations is approximately $72.8 \%$ in 2016, down from $76.8 \%$ in 2015 .

The state pension data indicate that all of the 50 states have pension plan obligations that exceed the market value of pension plan assets. Stated differently, each of the 50 states had pension plan obligations which were greater than the market value of the pension plan assets as of the end of the 2016 fiscal year. Seven states had a market value of pension plan assets between $90 \%$ and $100 \%$ of plan obligations, and seven others had a market value of pension plan assets between $80 \%$ and $90 \%$ of plan obligations. Additional details concerning the market value of pension plan assets for each of the 50 state pension plans (excluding local governments) are shown in Exhibit 2.

As the bar graph in Exhibit 2 indicates, 14 states had a market value of plan assets that was between $70 \%$ and $80 \%$ of the projected pension obligation and 12 states had a market value of plan assets that was between $60 \%$ and $70 \%$ of the projected pension obligation as of the end of 2016 fiscal year.

Moreover, the six states with the largest pension plan obligations include California, Illinois, New Jersey, Pennsylvania, Texas and Ohio, and their combined pension obligation totaled $\$ 588.5$ billion as of 2016. Details regarding the level of each state's pension plan obligations are as follows:

Several trends are notable when comparing the 2015 and 2016 pension data collected by the U.S. Census Bureau. First, only 2 states had a decrease in pension liability from 2015 to 2016. That means that 48 states had either its pension surplus eliminated or an increase in its pension plan liability. On a percentage basis, the state of North Carolina had the largest increase in its pension liability with an increase of approximately $250 \%$. New York and Montana were second and third, with increases of $151 \%$ and $140 \%$, respectively. Minnesota had the largest dollar increase in its pension liability from 2015 to 2016 with over a $\$ 9.1$ billion increase. Florida and Pennsylvania were second and third with pension liability 
Exhibit 2
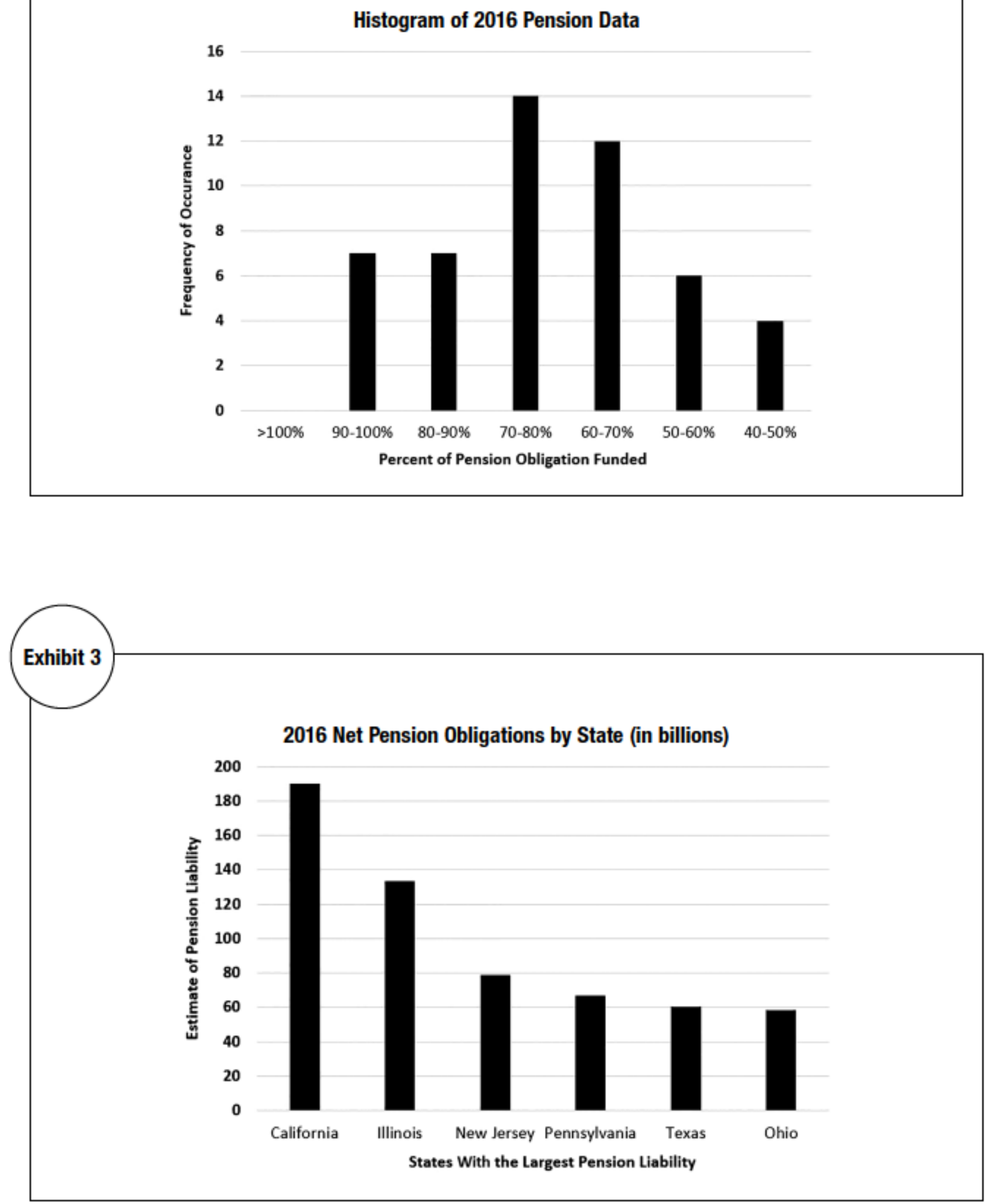
increases of $\$ 9.0$ and $\$ 7.8$

billion, respectively.

\section{SUMMARYANDDISCUSSION}

In the above sections, we highlight negative trends in the DB pension plans of government entities in the United States. We note credit rating downgrades and increased borrowing costs as a result of ballooning DB pension plan liabilities. We also note decreased public services as government entities try to fund increased DB pension costs. In 2016, U.S. government entities had DB pension liabilities of over \$1 trillion. Even more troubling is that the liabilities reported by government entities would be much larger if they utilized more reasonable and conservative discount rates.

We also highlight differences in trends of DB pension plans between the private and public sectors. Businesses have shifted away from DB pension plans as a vehicle for employee retirement. While the majority of the Fortune 500 offered DB plans to employees in the 1980s, they now offer DC plans. The reasons for the shift include higher costs, financial market risk, and liability recognition associated with DB plans. DC plans are less costly and entail no financial market risk to the employer. They also do not require liability recognition if the market value of retirement assets is less than the present value of future payments to retired employees. In contrast to private business, the majority of government entities still utilize DB pension plans. As reported above, a 2016 study found that $85 \%$ of government employees still have access to a DB plan. The result is that government entities in the United States have increased the amount they owe to current and future government retirees.

There are positives and negatives when government entities shift away from DB pension plans. The benefits include reduced government spending and avoidance of the ripple effect of increased DB pension liabilities discussed above. When government entities switch to DC pension plans, it helps government entities reduce their employee benefit costs. In addition, they can alleviate the negative side effects of increased pension obligations, which include increased interest and borrowing costs. The negative side effects of employers switching to DC plans include:

1. The risk to adequately fund one's retirement falls to the employee. Extant research 冈nds this shift in risk from employer to employee to be problematic as employees often do not have the 冈nancial literacy required to make investment decisions (Brown, 2016).

2. DC plans do not always have as many investment options as DB plans and DC plans often have higher administrative fees which makes them less ef囚cient investment choices (Broadbent, Palumbo, \& Woodman, 2006).

3. The drop in employee pension costs due to DB pension plan reforms could have unfortunate side effects. For example, Elder and Wagner (2016) report that if government pension reforms result in the accumulation of too many pension assets, it is pos- sible that policymakers might be pressured to increase other employee bene囚ts.

While there are pros and cons of switching from DB plans, it's apparent that government entities should be more disciplined about funding them. As government entities continue to offer DB plans, pension reform is needed and essential.

\section{REFERENCES}

Aneiro, M. (2014, November). Bondholders and pension risk. Barron's. Retrieved from http://www.barrons .com/articles

Attmore, R. H., \& Ives, M. (2015). GASB's governmental fund reporting model is seriously flawed. Journalof GovernmentFinancialManagement, 64(1), 24-30.

Bagchi, S. (2014). Promise now, pay later. Pensions\&Investments, 42(26), 12.

Broadbent, J., Palumbo, M., \& Woodman, E. (2006, December). The shift from defined benefit to defined contribution pension plans-Implications for asset allocation and risk management. Bank for International Settlements. Retrieved from http://www.bis.org/publ/wgpapers

Brown, E. F. (2016). Lessons from efforts to manage the shift of pensions to defined contribution plans in the United States, Australia, and the United Kingdom. AmericanBusiness Law Journal, 53(2), 315-382. doi:10.1111/ablj.12079

Bryan, B. (2016, April). The U.S. government has a \$20.4 trillion retirement problem. BusinessInsider . Retrieved from http://www.businessinsider.com

Civic Federation. (2016, September). Another Chicago pension fund reduces its assumed rate of return on investment. Retrieved from https://www .civicfed.org

Collins, C., \& Rettenmaier, A. J. (2010). Policy Report No. 329: Unfunded liabilities of state and local government employee retirement benefit plans. National Center for Policy Analysis. Retrieved from http://www.ncpa.org

Devitt, C., \& Shields, Y. (2015, September). Illinois infrastructure crumbles amid budget warfare. BondBuyer. Retrieved from https://www.bondbuyer.com 
Edwards, J. (2016, August). Pensions: The vast, unfair transfer of $£ 36$ billion in wealth that no one is talking about. Business Insider. Retrieved from http:// www.businessinsider.com

Elder, E. M., \& Wagner, G. A. (2016). Can public pensions fulfill their promises? An examination of Pennsylvania's two largest public pensions. Municipal FinanceJournal, 37(3), 1-22.

Farmer, L. (2014, November). The week in public finance: Broke in Pennsylvania, bankruptcy lessons and pensions. GoverningtheStatesandLocalities. Retrieved from http://www.governing .com/

Farmer, L., \& Maciag, M. (2015, March). Why some public pensions could soon look much worse. GoverningtheStates andLocalities. Retrieved from http:// www.governing.com

Faulk, D., Hicks, M., \& Killian, L. (2016). What factors affect the underfunding of local pensions? Evidence from Indiana. PublicFinance\& Management, 16(2), 98-120.

Fitzpatrick, D., \& Martin, T. W. (2014, August 14). Facing a pension shortfall, San Diego dials up the risk. WallStreet Journal-EasternEdition, A1-A2.
Fletcher, M. (2014, February 25). In San Jose, generous pensions for city workers come at expense of nearly all else. WashingtonPost. Retrieved from https://www.washingtonpost.com

Folton, C., Flesher, D. L., Previts, G. J., $\&$ Stone, M. S. (2017). State and local government pensions at the crossroads: Updating accounting standards highlight the challenges. CPAJournal, 87(4), $42-51$.

Governmental Accounting Standards Board. (2012, June). GASB Statement No. 68: Accountingandfinancial reportingf orpensions - anamendment of GASBStatementNo.27. Retrieved from http://www.gasb.org

Katz, M. (2017, May). Michigan business leaders propose pension overhaul. AiCIONews . Retrieved from https:// www.ai-cio.com

Killian, L., Faulk, D., \& Hicks, M. (2016). The hidden costs of underfunded pensions. Journalof GovernmentFinancial Management, 65(1), 20-24.

Martin, T., Kantchev, G., \& Narioka, K. (2016, November 14). Era of low interest rates hammers millions of pensions around world. WallStreetJournalEasternEdition, A1.
Matthews, C. (2016, July). California's pension funding crisis just got worse. Fortune. Retrieved from http://www.fortune.com

McFarland, B. (2015, September). Defined contribution plan volatility: Timing is everything. WillisTowers Watson. Retrieved from www.towerswatson.com

Mead, M. (2008, March). State and local government use of generally accepted accounting principles for general purpose external financial reporting. GASBResearchBrief. Norwalk, CT.

Mortimer, J. W., \& Henderson, L. R. (2014). Measuring pension liabilities under GASB Statement No. 68. Accounting Horizons, 28(3), 421-454.

Shane, A., \& Woeppel, S. (2015, August). The challenge of the pension crisis on municipal credit. InstitutionalInvestor (p. 21). Retrieved from http://www institutionalinvestor.com

Sigo, S. (2016, April). Kentucky boosts pensions using funds from agency cuts. BondBuyer. Retrieved from https:// www.bondbuyer.com.

Walters, D. (2016, September 11). California's unfunded pension debts may be larger than acknowledged. Sacramento Bee. Retrieved from http://www .sacbee.com 